\title{
Genetically Modified Organism (GMO): What is it? Its Development and Future
}

\author{
Ümmügülsüm Güzelsoy ${ }^{1 *}$ and Müyesser Kuşcu² \\ ${ }^{1}$ Yıldız Technical University, Faculty of Arts and Science, Department of Molecular \\ Biology and Genetics \\ ${ }^{2}$ Giresun University, Faculty of Engineering, Food Engineering \\ *Corresponding Author: Ümmügülsüm Güzelsoy, Yıldız Technical University, \\ Faculty of Arts and Science, Department of Molecular Biology and Genetics.
}

Received: February 12, 2020

Published: March 03, 2020

(C) All rights are reserved by Ümmügülsüm

Güzelsoy and Müyesser Kuşcu.

\section{Abstract}

With the rapid increase in the world population, the development of gene technology has also accelerated to meet basic needs. It is possible to obtain more efficiency from agricultural products in a short time, to obtain enriched products by working on nutrient contents, and to produce solutions against the development of diseases caused by the increase in population thanks to biotechnology.

Groups that support genetically modified organisms act to improve the shelf life and organoleptic properties of fruits and vegetables in order to increase the yield of plant and animal products to produce the necessary vaccines and drugs for the treatment of human diseases. In addition to improving the quality of nutrition with this technology, researchers also guide organ transplants. They are of the opinion that there will be many benefits.

The distribution of the species in the nature and their negative effects on the balance between them, toxic effects in plants, the difficulty of the fight against pathogens due to the development of gene resistant against antibiotics, the increase of the risk of allergic reactions due to transfers between genes, led to the emergence of question marks about genetically modified organisms.

All these positive and negative effects have affected countries' approaches to genetically modified organism technology. The areas of use of genetically modified organisms worldwide, frequency of use, evaluation, legislative practices and the importance of labeling vary by country.

Keywords: Genetically Modified Organisms; Gene Delivery Technology; GMO; GM

\section{Introduction}

Human beings have turned to biotechnology as a result of the increasing and intensifying demands in agriculture as well as in all fields in parallel with the changes it has experienced as a result of what has happened in the historical process and especially the developments in science and technology [1].

Development of biotechnology BC It started at a simple level with the fermentation of yeast products and microorganisms and classical biotechnology, from which essential nutrients such as wine, cheese, yogurt and bread are obtained. Later, modern biotechnology was developed with the use of advanced technological methods and further products were started to be developed by going further than basic nutrients [2].

Biotechnology research has increased with developing technology. Modern biotechnology has introduced Recombinant DNA technology. "Recombinant DNA Technology" enables the ability to change the characteristics of living organisms through gene transfer and enables the genetic characteristics of any living thing to be transferred to another living creature, which cannot be realized within natural processes. With this technology, it enables the improvement of the genetic characteristics of a plant or animal and the creation of new resistant species. 
With the genetic modification method, gene transfer is also possible between different species that cannot be performed by conventional methods. "Recombinant DNA Technology", which enables gene transfer between species, and "Genetically Modified Organism" (GMO) have been used for these purposes [3].

Organisms produced using genetic engineering technology are GMO, genetically modified products (GM products), gene transfer organisms, transgenic organisms, bioengineering organisms, etc. in the literature. are defined by names. The genes transferred to these organisms are expressed as transgenes [4-5].

We see that GMOs are now applied in almost every field in our lives, such as health (red biotechnology), agriculture (green biotechnology), industry (white biotechnology) and marine products (blue biotechnology).

Genetically changed organism groups: Plants, animals, microorganisms

Increasing agricultural yield is possible by increasing agricultural areas or increasing the yield that can be obtained from scarce land. In order to increase the agricultural area yield, the genetic characteristics of the plants should be improved, while advanced agricultural techniques should be used correctly. Although the pesticides used to combat irrigation, fertilizer application and plant pests have a positive effect on yield, it is an undeniable fact that the wrong and unconscious application of these methods negatively affects ecology. For this reason, it is thought that increase in agricultural yield is possible if the genetic structures are improved and chemical inputs are used with the correct application [6].

Foods can never be completely safe despite all the technological advances. Food safety is threatened by a wide variety of pathogens that can cause foodborne illnesses, algae toxins that cause severe acute ailments, and fungal toxins that cause acute and chronic conditions such as tetratogenic, immunotoxic, nephrotoxic and estrogenic effects. Today, developments in food production processes are generally aimed at increasing food safety. Production of genetically modified products such as the use of additives, pesticides, drying processes and similar processes is also carried out with the aim of ensuring food safety [7].

Studies on agricultural new product design and animal production carried out in the field of molecular biology paved the way for the formation of new species with high productive properties
[8]. FDA (American Food and Drug Administration) only allowed GM product production of vegetable origin, although efforts to produce genetically modified products in animal products were also allowed in some countries [7,9].

The purpose of the studies conducted on genetically modified plants in the world is based on the principle of obtaining plants that are resistant to diseases and pests, whose product quality is improved and some features are improved.

In addition to damaging the plants by eating plant parts, insects cause indirect damage by carrying disease factors such as viruses, bacteria and fungi.

The most commonly transferred feature is resistance to herbicides, which significantly reduces the production costs of farmers. Bacillus thuringiensis endotoxin gene (Bt), which also provides resistance to Lepidopters, is effective against caterpillars that are harmful especially in corn and cotton growing; hence, it reduces the use of pesticides, thus reducing the cost of production and eliminating the negative effects of chemical medicines on the environment and human health [10].

Genetic modification studies are still in corn, cotton, potatoes, etc. resistance to pests in products; soy, cotton, corn, rapeseed, paddy, etc. resistance to weed medicines in crops; resistance to viral plant diseases in potatoes, paddy, corn; sunflower, soybean, peanut etc. increasing vegetable oil quality in products; tomatoes, strawberries, etc. It is used for delaying ripening in products (extending shelf life), increasing flavor in tomato [11].

Along with the genetic modifications performed in herbal products, genetic modification studies have also been carried out on animals. The biggest example of these studies is the copying of Dolly sheep from the breast cells of an adult sheep. Genetic modifications in animals have been required in most biomedical studies.

An example of this is the transfer of the genetic code to the first GM sheep named after Dolly, which causes hemophilia disease, helps to clot the blood, enables the production of Factor-9, in case of deficiency [12].

Examples of the use of GM animals for food production are the production of high casein milk to increase cheese productivity, gene transfers that will give high milk yield in cows, and production 
of lactose-free or lactose-free milk for people who are sensitive to lactose. In addition, studies for egg production with low cholesterol content, studies that support growth or provide resistance to cold conditions for fish are ongoing. Discussions continue about the production and commercial use of genetically modified products. Controlled production continues in some places in the UK, although the European Union does not stay close to these studies because it is afraid of public reactions. In addition, production of GD products for small scale trials continues in countries such as Bulgaria, Germany, Romania and France [10-13].

Turkey is also, with the condition that the Ministry of Food Agriculture and Livestock subject to approval while biotechnology research is ongoing work carried out in the Middle East Technical University. Currently, no genetically modified products are produced in series [13].

Benefits of genetically changed organisms

Hunger and nutritional deficiencies are among the problems in public health. To prevent this problem, it is planned to increase the food products and enrich the contents of the produced foods [14].

As a result, scientists developed genetically modified agricultural products enriched with certain vitamins [15]. Regarding this issue, beta rice and golden rice with increased vitamin A content can be given as examples. With these products, 170 million people with vitamin A deficiency are aimed to get sufficient vitamin A, especially in poor regions such as Southeast Asia [16]. By increasing the amount of antioxidant substances such as carotenoids, flavonoids and lycopene, it can contribute to general health [15].

Efforts are also made to improve health in vaccine and drug production. With these studies, it is aimed to produce safer production with lower costs. Although vaccination studies are still at the experimental stage, important steps have been taken in insulin production [17].

It works with genetically modified animals, especially in the field of food production. With the encouragement of increasing growth hormone, it is aimed to increase animal production and consumption with many different effects such as increasing meat production, increasing cheese production by increasing the amount of casein, removing lactose from the milk structure for lactose-sensitive individuals [15].

\section{Risks of genetically changed organisms}

Biotechnology field has great benefits in solving environmental problems, but it can cause various problems [18]. Unlike rainforest, bioengineered forests consisting of genetically modified trees do not bloom and secrete toxins to kill herbicide-resistant wolves and other insects. In addition, these forests cannot provide shelter for insects, fungi, birds and mammals and negatively affect the ecosystem [19]. With the transfer of genes, gene exchange between genetically modified products and natural products cannot be prevented. For this reason, its rich biodiversity is replaced by genetically modified homogeneous products [18].

Another issue that is discussed about GMOs is the state of resistance genes. It is stated that as a result of these genes passing to pathogenic microorganisms, it will be difficult to fight infections caused by bacteria [20].

\section{Conclusion}

In line with the rapidly developing world population, production and consumption of GMO products are increasing day by day. There is a risk of GMO in many foods we consume in daily life. When looking at the development of genetically modified organisms, it is recommended not only to be considered beneficial and to ignore possible risks. It is considered that it is socially important that GMO products should be analyzed in all dimensions and it will be appropriate to proceed to the production stage as a result of researches.

\section{Bibliography}

1. Güngören A. "Genetiği Değiștirilmiş Tarım Ürünlerinin Türkiye Açısından Değerlendirilmesi”. Ankara Üniversitesi Fen Bilimleri Enstitüsü Yüksek Lisans Tezi Ankara (2012).

2. Kıymaz $\mathrm{T}$ and Tarakçığlu M. “Biyoteknoloji Alanındaki Gelişmelerin Yansımaları ve Türkiye’nin Politika Seçenekleri. Planlama Dergisi, Özel Sayı, DPT’nin Kuruluşunun 42". Yılı DPT (2004): 235-242.

3. Mutlu Ş. Piyasada satışa sunulan cips ve gevreklerde GDO varlığının araștırlması (2016).

4. Uzogara SG. "The Impact of Genetic Modification of Human Foods in the 21st Century". Biotechnology Advances 18 (2000): 179-206.

5. Cellini F., et al. "Unintended Effects and Their Detection in Genetically Modified Crops". Food and Chemical Toxicology 42 (2004):1089-1125. 
6. Haspolat I. "Genetiği değiștirilmiş organizmalar ve biyogüvenlik". Ankara Üniversitesi Veteriner Fakültesi Dergisi 59 (2012): 75-80.

7. Borchers A and Teuber S. "Food Safety". Clinical Reviews in Allergy and Immunology 39 (2010): 95-141.

8. Kulikov AM. "Genetically Modified Organisms and Risks of Their Introduction". Russian Journal of Plant Physiology 52.1 (2005): 115-128.

9. Domingo JL and Bordonaba JG. "A literatüre review on the safety assessment on genetically modified plants". Environment International 37 (2011): 734-742.

10. Yorulmaz S and Ay R. "Genetiği Değiștirilmiş Organizmaların (GDO) Entomoloji Alanındaki Uygulama Olanakları”. Süleyman Demirel Üniversitesi Ziraat Fakültesi Dergisi 1.2 (2006): 53-59.

11. Atsan $\mathrm{T}$ and Erem Kaya T. "Genetiği Değiştirilmiş Organizmaların (GDO) Tarım ve İnsan Sağlı̆̆ı Üzerine Etkileri. U. Ü”. Ziraat Fakültesi Dergisi 22.2 (2008): 1-6.

12. Çelik V and Balık DT. "Genetiği Değiștirilmiş Organizmalar". Erciyes Üniversitesi Fen Bilimleri Enstitüsü Dergisi 23.1-2 (2007): 13-23.

13. Kulaç İ and Ağırdil Y. "Sofralarımızdaki Tatlı Dert, Genetiği Değiştirilmiş Organizmalar ve Halk Sağlığına Etkileri”. Türk Biyokimya Dergisi 31.3 (2006): 151-155.

14. Kaynar P. “Genetik Olarak Değiștirilmiş Organizmalar (GDO)'a Genel Bir Bakış”. Türk Hijyen ve Deneysel Biyoloji Dergisi 66.4 (2009): 177-185.

15. Çelik V and Ve Balik DT. "Genetiği Değiştirilmiş Organizmalar (GDO)”. Erciyes Üniversitesi Fen Bilimleri Enstitüsü Dergisi 23.1-2 (2007): 13-23.

16. Atsan T and Ve Kaya TE. "Genetiği Değiștirilmiş Organizmaların (GDO) Tarım Ve İnsan Sağlığı Üzerine Etkileri”. Uludağ Üniversitesi Ziraat Fakültesi Dergisi 22.2 (2008): 1-6.

17. Haspolat I. "Genetiği Değiștirilmiş Organizmalar ve Biyogüvenlik". Ankara Üniversitesi Veteriner Fakültesi Dergisi 59 (2012): 75-80.

18. Bezirganoğlu İ. "Genetiği Değiștirilmiș Organizmalar Ve Biyogüvenlik”. Pegem Atıf İndeksi (2017): 1-289.
19. Hayirlidağ M., et al. "Genetiği Değiștirilmiş Gıdalar İle İlgili Etik ve Hukuki Tartışmalarve Kıtalararası Durum Değerlendirmesi”. Tarım Ekonomisi Dergisi 22.1 (2016): 1-9.

20. Kulaç İ., et al. "Sofralarımızdaki Tatlı Dert, Genetiği Değiștirilmiș Organizmalar ve Halk Sağlığına Etkileri”. Türk Biyokimya Dergisi 31.3 (2000): 151-155.

\section{Assets from publication with us}

- Prompt Acknowledgement after receiving the article

- Thorough Double blinded peer review

- Rapid Publication

- Issue of Publication Certificate

- High visibility of your Published work

Website: https://www.actascientific.com/

Submit Article: https://www.actascientific.com/submission.php Email us: editor@actascientific.com

Contact us: +919182824667 